\title{
Posttraumatic Growth pada Remaja Wanita yang Mengalami Kekerasan dalam Pacaran Ditinjau dari Perceived Social Support dan Variabel Demografi
}

\author{
Humaira Syahnya Almas ${ }^{1 *}$, Chandradewi Kusristanti ${ }^{2}$ \\ Universitas YARSI Jakarta \\ ${ }^{1}$ chandradewi.kusristanti@yarsi.ac.id, ${ }^{2}$ chandradewi.kusristanti@yarsi.ac.id \\ *Correspondence
}

\section{Article Information:}

Received 11 March 2021

Revised 22 August 2021

Accepted 06 September 2021

\section{Keywords:}

posttraumatic growth; perceived social support; trauma; dating violence; adolescence

\section{Kata Kunci:}

posttraumatic growth; perceived social support, trauma; kekerasan dalam pacarana; remaja wanita

\section{Abstract}

Dating violence cases are increasing every year in Indonesia. Despite violence being one of the traumatic events, it does not rule out the possibility that the survivors experienced growth after trauma called posttraumatic growth (PTG). This study aims to determine the contribution of perceived social support (PSS) towards posttraumatic growth (PTG) among adolescent women who experienced dating violence $(\mathrm{n}=308)$. This research is a quantitative study, with an F-Soz U K-14 questionnaire $(\alpha=$ $0.817)$ to measure PSS and PTGI-SF scale $(\alpha=0.89)$ to measure PTG. Using statistical regression was found that PSS had a significant role towards PTG $(\mathrm{R} 2=.186, \mathrm{p}=.000)$. The result of this study can be useful as a basis in educating the importance of support given by significant others for adolescent women exposed to violence during or after the violence happened.

Abstrak
Kasus kekerasan dalam pacaran meningkat setiap tahun di
Indonesia. Meski kekerasan merupakan salah satu bentuk
peristiwa traumatis, tidak menutup kemungkinan penyintas
mengalami pertumbuhan setelah trauma yang disebut sebagai
posttraumatic growth (PTG). Penelitian ini bertujuan untuk
mengetahui peran perceived social support (PSS) terhadap
posttraumatic growth (PTG) pada remaja wanita yang
mengalami kekerasan dalam pacaran $(\mathrm{n}=308)$. Penelitian ini
menggunakan pendekatan kuantitatif dengan kuesioner PTGI-SF
untuk mengukur PTG ( $\alpha=0.817)$ dan kuesioner F-SozU K-14
untuk mengukur PSS pada partisipan $(\alpha=0.89)$. Dengan
menggunakan regresi sederhana, terdapat peran yang signifikan
sebesar 18.6 \% dari perceived social support (PSS) terhadap
posttraumatic growth (PTG) ( $\left.R^{2}=.186, p=.000\right)$. Hasil
penelitian ini dapat bermanfaat untuk menjadi landasan dalam
mengedukasi pentingnya dukungan dari orang terdekat bagi
remaja wanita yang mengalami KDP.




\section{PENDAHULUAN}

Wanita merupakan salah satu kelompok yang paling rentan dalam mengalami kekerasan. World Health Organization atau WHO (2021) mengungkapkan bahwa 30\% wanita di dunia pernah mengalami kekerasan. Jumlah kasus kekerasan terhadap perempuan sepanjang tahun 2020 sebesar 299.911 kasus, dalam hal ini 20\% dari jumlah tersebut merupakan kasus kekerasan dalam pacaran (Komnas Perempuan, 2021). Berdasarkan Catatan Tahunan (CATAHU) 2020 yang dilansir oleh Komnas Perempuan terdapat 8.234 kasus kekerasan yang dilaporkan, sebanyak 1.309 merupakan kasus kekerasan dalam pacaran (Komnas Perempuan, 2021). Angka-angka tersebut patut menjadi perhatian, terutama karena kasus kekerasan kerap disebut sebagai fenomena gunung es, yaitu angka yang dilaporkan lebih sedikit dibandingkan kondisi aktualnya. Purnama (2016) mengemukakan salah satu penyebab kekerasan dalam pacaran (KDP) adalah adanya bias gender yang biasanya disebabkan oleh stigma masyarakat terhadap ketidaksetaraan kedudukan antara perempuan dan laki-laki yang dapat merugikan perempuan. Sejalan dengan hal tersebut, hasil penelitian menunjukkan bahwa remaja wanita memiliki peluang lebih besar menjadi korban KDP dibandingkan lelaki (Richards \& Branch, 2012).

Kekerasan dalam pacaran (KDP) merupakan bentuk kekerasan pada relasi romantis yang terjadi pada usia remaja dan mengakibatkan kerugian bagi salah satu pihak (Vagi dkk., 2013). Konsekuensi negatif yang dapat diterima oleh salah satu pihak dapat berupa permasalahan psikologis(Brown dkk., 2009; Mardiah dkk., 2020), cedera fisik (Swahn dkk., 2010), penyakit menular seksual (Mardiah dkk., 2020) dan penggunaan obat-obatan terlarang (Mardiah dkk., 2020). Akibat kerugian yang dialami oleh korban, KDP dapat dikatakan sebagai kejadian traumatis. Hal ini diperkuat oleh pernyataan (Jouriles dkk., 2012)) bahwa KDP dianggap sebagai kejadian traumatis karena memiliki dampak buruk pada fisik dan psikis korban.

Sejauh ini, beberapa penelitian mengenai kekerasan, termasuk KDP, berfokus pada konsekuensi negatif dari kekerasan yang dialami korban, seperti depresi, posttraumatic stress disorder (PTSD) (Rodriguez dkk., 2008), kecanduan alcohol (Temple \& Freeman, 2011), kecemasan dan bunuh diri (Pico-Alfonso dkk., 2006). Sebaliknya, terdapat beberapa penelitian juga menemukan adanya aspek lain yang cenderung positif dari terpapar kekerasan seperti kesadaran akan pentingnya hubungan yang suportif, sikap memaafkan, saling membantu (Flasch, Murray, \& Crowe, 2017). Sementara itu, (Tedeschi \& Calhoun, 2004)) mengungkapkan bahwa individu yang mengalami kejadian traumatis, termasuk kekerasan, sering kali mengalami perubahan dan pertumbuhan positif yang dinamakan sebagai posttraumatic growth (PTG). PTG merupakan kondisi dimana individu memiliki pandangan yang lebih baik setelah mengalami kejadian traumatis, ditandai dengan perubahan menjadi lebih baik pada hubungan dengan orang lain serta lebih mengapresiasi kehidupan (Kunst, 2011; Tedeschi \& Calhoun, 2004). 
Salah satu faktor eksternal yang dapat berpengaruh terhadap PTG yang dialami individu adalah dukungan sosial. (Rahmah dkk., 2017)) menjelaskan bahwa perubahan persepsi pada diri individu yang telah mengalami kejadian traumatis serta adanya dukungan dari lingkungan sekitar membantu penyintas mengalami perubahan positif. (Žukauskienė dkk., 2019)) menjelaskan bahwa dukungan sosial memiliki peranan dalam PTG dan kesejahteraan individu yang mengalami kejadian traumatis. Hasil penelitian yang dilakukan oleh Zhou, Wu, dan Zhen (2016) menggambarkan bahwa adanya korelasi positif yang signifikan antara dukungan sosial dan PTG pada remaja. Selain itu, sejumlah penelitian mengenai dukungan sosial dan PTG pada korban yang mengalami kejadian traumatis hasilnya menunjukkan adanya korelasi positif yang signifikan antara kedua variabel tersebut (Dirik \& Karanci, 2008; Nenova dkk., 2008; (Anderson dkk., 2012)).

Dukungan sosial dapat didefinisikan sebagai dukungan yang didapatkan dari lingkungan sekitar yang membuat individu merasa lebih berharga dan dicintai (Xia dkk., 2012). Salah satu bentuk dari dukungan sosial merupakan perceived social support (PSS) atau dukungan sosial yang dipersepsikan. (Fydrich dkk., 1999)) sebagai tokoh awal yang meneliti mengenai perceived social support (PSS) mendefinisikan perceived social support (PSS) sebagai dukungan yang dirasakan dan diharapkan dari lingkungan sekitar. Penelitian yang dilakukan menemukan bahwa PSS dapat membawa perubahan positif bagi korban KDP. Hal ini karena PSS dapat menurunkan tingkat kecemasan bagi remaja yang mengalami suatu permasalahan, dalam hal ini salah satunya merupakan KDP (Xia dkk., 2012). Selain itu, dukungan sosial yang dipersepsikan oleh individu dapat berpengaruh terhadap skema baru yang dimiliki oleh individu terhadap dirinya pasca trauma (Ogińska-Bulik, 2013). Perubahan skema yang dialami oleh remaja yang mengalami KDP dipengaruhi oleh adanya pendampingan yang diberikan oleh significant others (Richards \& Branch, 2012).

Pada akhirnya, dapat disimpulkan bahwa sejauh ini sejumlah penelitian berfokus pada dampak negatif yang dialami oleh individu yang terpapar kekerasan. Sementara itu, konsep PTG sebagai salah satu hal positif yang dapat muncul setelah individu terpapar peristiwa negatif yang traumatik tidak terlalu banyak diteliti. Sementara itu, disebutkan beberapa penelitian remaja wanita cenderung tergabung dalam beberapa kelompok pertemanan serta memiliki significant other yang setia mendampingi mereka. Adanya significant other meningkatkan peluang individu mengalami PTG pasca kejadian traumatis. Persepsi bahwa adanya dukungan dari orang lain termasuk dari significant others, yang merupakan inti dari konsep PSS, dapat membantu individu memiliki pandangan hidup yang baru mengenai kehidupan pasca kejadian traumatis, yang mengarah pada pertumbuhan PTG. Dengan demikian, melalui penelitian ini, peneliti ingin mengetahui signifikansi kontribusi PSS dalam menumbuhkan PTG pada remaja wanita yang mengalami kekerasan dalam pacaran. 


\section{METODE}

Penelitian ini menggunakan metode kuantitatif dengan tipe penelitian korelasional. Variabel prediktor pada penelitian ini merupakan perceived social support (PSS), sedangkan variabel kriterianya adalah posttraumatic growth (PTG). Populasi pada penelitian ini adalah remaja wanita yang mengalami kekerasan dalam pacaran. Sementara itu, yang menjadi sampel pada penelitian ini merupakan remaja wanita yang berada pada rentang usia 15 hingga 20 tahun, terindikasi mengalami kekerasan dalam bentuk fisik, verbal dan/ atau seksual melalui TALE Checklist sebagai alat screening. Teknik sampling yang digunakan pada penelitian ini adalah purposive sampling. Purposive sampling merupakan teknik sampling yang digunakan peneliti untuk memastikan bahwa sampel pada suatu penelitian merupakan sampel yang tepat sehingga dapat memberikan informasi yang tepat untuk penelitian (Kumar, 2011).

Pengambilan data seluruhnya dilakukan secara daring, karena adanya pandemi membuat peneliti tidak mungkin mengambil data secara luring. Selain itu, sebagian besar remaja menggunakan media sosial sehingga memudahkan akses peneliti untuk mengumpulkan partisipan. Dengan demikian, penyebaran kuesioner dilakukan via personal chat melalui aplikasi WhatsApp ataupun via platform media sosial seperti Twitter dan Instagram. Dengan metode pengambilan data tersebut, sebanyak 405 partisipan telah mengisi kuesioner penelitian ini. Namun, setelah dilakukan screening kembali, hanya data dari 308 partisipan yang diolah, karena telah memenuhi kriteria sampel. Untuk memastikan bahwa sampel sesuai dengan kriteria, screening dilakukan melalui TALE Checklist. Screening tersebut dilakukan untuk memastikan bahwa partisipan memiliki pengalaman menjadi penyintas kekerasan yang dilakukan oleh pacar atau mantan pacar.

Untuk mengukur PTG pada partisipan, penelitian ini menggunakan alat ukur Posttraumatic Growth Inventory-Short Form (PTGI-SF) yang diadaptasi oleh Cann dkk. pada tahun 2010. PTGI-SF merupakan bentuk pendek dari PTGI yang dikemukakan pertama kali pada tahun 1996 oleh Tedeschi dan Calhoun. PTGI-SF dibentuk untuk memudahkan dalam pengambilan data, karena penggunaan kuesioner dengan jumlah lebih sedikit tidak memerlukan banyak waktu dan energi dalam pengambilan data. Dengan demikian, PTGI-SF tepat dipakai bagi individu yang sedang beradaptasi dari krisis yang dialami (Cann dkk., 2010). Selain itu, aitem yang dipilih dalam PTGI-SF didasarkan pada sampel yang besar dan heterogen untuk memastikan bahwa PTGI-SF dapat digunakan secara luas (Cann dkk., 2010).

PTGI-SF terdiri dari 10 aitem dengan skala Likert 6 poin, dengan rentang 0 (Tidak mengalami perubahan) hingga 5 (Mengalami perubahan dengan tingkat yang sangat besar). Peneliti melakukan proses adaptasi PTGI-SF dengan melakukan proses translasi (forward dan backward), expert judgement, uji keterbacaan dan try out. Dalam proses translasi, peneliti menggunakan jasa penerjemah bahasa asing dan dilanjutkan dengan proses expert judgement oleh dua orang ahli. Peneliti menyesuaikan aitem dari hasil 
translasi dan hasil dari expert judgement untuk kemudian dilakukan uji keterbacaan kepada partisipan yang sesuai karakteristik (6 partisipan) dan try out (30 partisipan). PTGI-SF memiliki lima dimensi, yaitu pandangan hidup yang baru, hubungan dengan orang lain, kekuatan personal, perubahan spiritualitas, dan apresiasi terhadap kehidupan (Cann dkk., 2010). Contoh aitem untuk dimensi hubungan dengan orang lain adalah "Saya memiliki kedekatan yang lebih besar dengan orang lain"; contoh untuk dimensi pandangan hidup yang baru "Saya membuat pola hidup yang baru"; contoh aitem untuk dimensi kekuatan personal "Saya mengetahui bahwa saya lebih kuat daripada yang sebelumnya saya kira"; serta contoh untuk dimensi apresiasi terhadap kehidupan adalah "Saya mengubah prioritas tentang hal penting dalam hidup".

Untuk mengukur variabel prediktor pada penelitian ini yaitu PSS, peneliti menggunakan alat ukur F-SozU K-14 yang diadaptasi oleh Fydrich dkk. pada tahun 2007. F-SozU merupakan pengembangan dari alat ukur Social Support Questionnaire yang dikembangkan oleh Fydrich dkk. pada tahun 1987 dan 1989 di Jerman. Menurut (Fydrich dkk., 1999) konsep PSS kembali pada pendekatan kognitif mengenai keyakinan subjektif bahwa adanya dukungan sosial dari lingkungan sekitar. Sejalan dengan hal tersebut, dukungan sosial dipahami sebagai hasil dari interaksi antara individu dan lingkungan sosial serta hasil evaluasi subjektif mengenai kedua hal tersebut. Lebih lanjut, dikatakan bahwa dukungan sosial yang dipersepsikan merupakan dukungan sosial yang lebih dapat digunakan dalam klinis-psikologis.

F-SozU K-14 merupakan alat ukur unidimensional dan menggunakan skor total untuk menentukan skor tiap partisipan. Fydrich, dkk. (2009) mengemukakan bahwa FSozU K-14 memiliki aitem yang sesuai untuk digunakan mengukur PSS. Lebih lanjut, Fydrich, dkk. (2009) mengemukakan bahwa F-SozU K-14 terbukti mampu membedakan dengan baik tingkat dukungan sosial yang dipersepsikan individu serta terbukti lebih efisien dalam hal durasi pengerjaan. F-SozU K-14 mengukur tiga dimensi PSS, yaitu integrasi sosial, dukungan emosional dan dukungan praktis. F-SozU K-14 terdiri dari 14 aitem dengan 5 poin skala Likert (1-5). Peneliti melakukan proses adaptasi F-SozU K14 dengan melakukan proses translasi (forward dan backward), expert judgement, uji keterbacaan dan try out. Dalam proses translasi, peneliti menggunakan jasa penerjemah bahasa asing dan dilanjutkan dengan proses expert judgement oleh dua orang ahli. Peneliti menyesuaikan aitem dari hasil translasi dan hasil dari expert judgement untuk kemudian dilakukan uji keterbacaan kepada partisipan yang sesuai karakteristik (6 partisipan ) dan try out (30 partisipan). Contoh aitem untuk dimensi integrasi sosial adalah "Ada beberapa orang yang memiliki minat yang sama dengan saya, sehingga saya nyaman mengerjakan berbagai hal bersama mereka"; contoh aitem untuk dimensi dukungan emosional, "Saya menerima banyak pengertian dan rasa aman dari orang lain"; serta salah satu contoh aitem untuk dimensi dukungan praktis adalah "Saya dapat dengan mudah menemukan seseorang yang menjaga rumah ketika saya tidak berada di rumah". 
Tabel 1. Reliabilitas Alat Ukur

\begin{tabular}{cc}
\hline Alat Ukur & Reliabilitas \\
PTGI-SF & .643 \\
F-SozU K-14 & .900 \\
\hline
\end{tabular}

Merujuk pada Guildford, koefisien reliabilitas $\alpha \geq 0,6$ menunjukkan reliabilitas yang tinggi pada suatu alat ukur (Nasrah, Jasruddin, \& Tawil, 2017). Tabel 1 di atas menunjukkan hasil pengujian reliabilitas alat ukur PTGI-SF $(\alpha=.643)$ dan alat ukur FSozU K-14 ( $\alpha=.900)$ pada tahap uji coba. Dari tabel tersebut, dapat disimpulkan bahwa kedua alat ukur reliabel untuk digunakan pada penelitian ini.

Tabel 2. Rentang Nilai Hasil Analisis Aitem

\begin{tabular}{cc} 
Corrected-item \\
correlation \\
Alat Ukur & $.050-.492$ \\
PTGI-SF & $.380-.784$ \\
F-SozU K-14 & \\
\hline
\end{tabular}

Sementara itu, analisis aitem dilakukan untuk melihat konsistensi yang dimiliki antar aitem pada suatu alat ukur (Kumar, 2011). Suatu aitem dinyatakan baik apabila memiliki rentang nilai corrected item-total correlation 0.25 hingga 0.30 (Azwar, 2015). Tabel 2 di atas menunjukkan hasil hasil analisis aitem pada alat ukur dalam tahap uji coba $(\mathrm{n}=.050-.784)$. Semua aitem berada pada rentang $0.205-0.784$, kecuali aitem nomor satu yang berbunyi "Saya mengubah prioritas saya mengenai hal yang penting dalam hidup saya" memiliki koefisien corrected inter item correlation di bawah 0.20. Pada aitem tersebut, dilakukan revisi aitem menjadi "Saya mengubah urutan hal-hal penting dalam hidup saya". Meskipun terdapat satu aitem yang memiliki koefisien dibawah 0.20, tetapi aitem tersebut memiliki koefisien yang positif dan secara keseluruhan hasil reliabilitas alat ukur dapat dikatakan baik. Selain itu, pada tahap uji keterbacaan, seluruh partisipan yang memenuhi karakteristik sampel juga tidak memberikan masukan atas aitem tersebut. Berdasarkan pertimbangan-pertimbangan tersebut, maka tim peneliti memutuskan untuk tetap mengikutsertakan aitem tersebut.

\section{PAPARAN HASIL}

Untuk melakukan uji regresi, perlu dilakukan uji normalitas, linearitas dan korelasi. Berdasarkan 236able 3, dapat disimpulkan bahwa data pada penelitian ini terdistribusi secara normal. Hal ini karena data dapat dikatakan terdistribusi secara normal apabila memiliki nilai signifikansi $p>0.05$ (Nasrum, 2018). Apabila ditemukan data tidak linear maka tidak dapat dilanjutkan dengan uji regresi. Merujuk pada Widhiarso (2010), apabila uji linearitas menunjukkan $p<0.05$, maka dapat dikatakan data membentuk garis linear. Berdasarkan 236able 4 dapat dikatakan data penelitian ini terbukti linear. Selain itu, merujuk pada 236able 5, terdapat korelasi yang signifikan antara PTG dan PSS ( $p$ $<.001)$. 
Tabel 3. Uji Normalitas

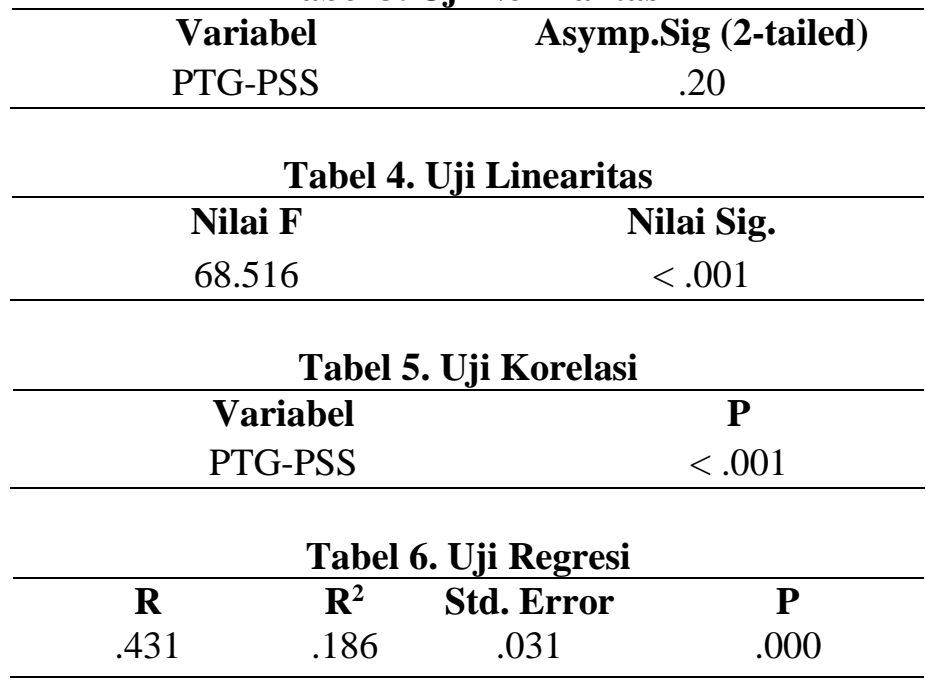

Berdasarkan 237able 6 dapat disimpulkan bahwa hasil dari uji regresi yang dilakukan, terdapat peran yang signifikan sebesar $18.6 \%$ dari perceived social support (PSS) terhadap posttraumatic growth (PTG) $\left(p=.000 ; R^{2}=.186\right)$.

\section{Tabel 9. Analisis Tambahan berdasarkan Data Demografi}

\begin{tabular}{|c|c|c|c|}
\hline Data Demografi & Nilai Signifikansi PTG & Mean & Standard Deviasi \\
\hline $\begin{array}{l}\text { Individu yang } \\
\text { sedang/masih menjalani } \\
\text { hubungan yang terdapat } \\
\text { KDP di dalamnya. }\end{array}$ & $<.001$ & $\begin{array}{l}37.225 \\
6.395\end{array}$ & \\
\hline $\begin{array}{l}\text { Individu yang sudah tidak } \\
\text { menjalani/sudah } \\
\text { meninggalkan hubungan } \\
\text { yang terdapat kekerasan di } \\
\text { dalamnya. }\end{array}$ & & $\begin{array}{l}40.526 \\
3.268\end{array}$ & \\
\hline Durasi Hubungan; & & 41.159 & \\
\hline $\begin{array}{l}\text { Individu yang menjalani } \\
\text { hubungan lebih dari } 12 \\
\text { bulan (>12 bulan). } \\
\text { Individu yang menjalani }\end{array}$ & & 6.201 & \\
\hline $\begin{array}{l}\text { hubungan dalam rentang } \\
12-24 \text { bulan (12-24 bulan). }\end{array}$ & $<.001$ & 40.986 & 6.114 \\
\hline $\begin{array}{l}\text { Individu yang menjalani } \\
\text { hubungan kurang dari } 12 \\
\text { bulan }(<12 \text { bulan) }\end{array}$ & & 39.075 & 6.449 \\
\hline
\end{tabular}

Peneliti melakukan uji beda menggunakan independent t-test untuk pelaku kekerasan dan one-way ANOVA untuk durasi hubungan. Uji beda dilakukan dilatarbelakangi oleh penelitian yang dilakukan oleh Cobb, dkk. (2006) yang mengemukakan bahwa wanita yang meninggalkan pasangannya yang abusive memiliki PTG yang lebih tinggi dibandingkan dengan wanita yang bertahan dengan pasangannya 
yang abusive. Merujuk pada tabel 9, diketahui bahwa terdapat perbedaan yang signifikan pada skor PTG jika ditinjau berdasarkan pelaku kekerasan $(p=<.001)$. PTG secara signifikan ditemukan lebih tinggi pada partisipan yang sudah meninggalkan pelaku kekerasan (mantan) $(M=40.526, S D=6.238)$, sedangkan partisipan yang masih menjalin hubungan asmara dengan pelaku melaporkan skor PTG yang lebih rendah $(M=37.255$, $S D=6.395)$.

Selain itu, uji beda menggunakan one-way ANOVA dilakukan kepada partisipan terkait durasi hubungan. Hal ini dilatarbelakangi dari sejumlah penelitian yang menunjukkan bahwa individu yang lebih sering terpapar kejadian traumatis menunjukkan tingkat pertumbuhan yang lebih tinggi ((Laufer dkk., 2009)2009; Cobb, dkk. 2006). Selain itu Anderson dkk., (2012) mengemukakan bahwa durasi waktu berada pada hubungan yang terdapat kekerasan juga memiliki pengaruh terhadap PTG yang dialami individu. Hasilnya menunjukkan ditemukan perbedaan secara signifikan pada variabel PTG ( $p=.024)$. Hasil dari post-hoc Tukey menunjukkan bahwa rata-rata PTG secara signifikan lebih tinggi pada partisipan yang menjalani hubungan selama lebih dari 24 bulan $(M=41.159, S D=6.201)$, diikuti dengan yang menjalani hubungan pada rentang $12-24$ bulan ( $M=40.986, S D=6.114)$, dan $0-12$ bulan $(M=39.075, S D=6.449)$.

\section{PEMBAHASAN}

Dukungan sosial dianggap menjadi salah satu aspek yang berperan penting terhadap pertumbuhan psikologis yang dialami oleh individu (Zhou dkk., 2016)(Linley \& Joseph, 2004). PSS merupakan salah satu bentuk dukungan sosial yang memudahkan individu mengalami pertumbuhan psikologis pasca kejadian traumatis (Sztonyk \& Formella, 2020; Tedeschi dkk., 2018; Nenova dkk., 2013; Jia dkk., 2013; Durak \& Karanci, 2010). Pihak-pihak yang berada di sekitar individu mempengaruhi PTG yang muncul pada individu setelah mengalami kejadian traumatis (Tedeschi \& Calhoun, 2007). Hal ini ditandai ketika individu memiliki significant others yang kerap memberikan afirmasi yang membangun, dan hal tersebut berpengaruh terhadap bagaimana individu dapat mengubah persepsinya pasca kejadian traumatis (Tedeschi dkk., 2018).

Penelitian terdahulu yang dilakukan oleh Holt dan Espelage (2005) mengemukakan bahwa individu yang memiliki tingkat PSS yang tinggi mampu untuk mengungkapkan kepada keluarga ataupun teman dekatnya terkait kekerasan yang dialami. Hasil penelitian tersebut menjadi penting untuk digunakan dalam menjelaskan adanya keterbukaan dari individu yang terpapar kekerasan berpengaruh terhadap keputusan individu untuk meninggalkan hubungan yang di dalamnya terdapat kekerasan. Hal ini karena adanya kesempatan berdiskusi dengan keluarga ataupun kerabat dekat mengenai apa yang dialami berpengaruh terhadap keputusan individu untuk meninggalkan pasangannya yang abusive. Selain itu, individu yang memiliki sosok yang dapat mendengarkan, mengerti, dan menemani di saat ataupun setelah mengalami kejadian traumatis cenderung tidak merasa kesepian (Kilmer \& Gil-Rivas, 2010). 
Jia dkk. (2013) menyatakan remaja wanita lebih merasa memiliki dukungan sosial dibandingkan laki-laki. Penelitian tersebut menemukan bahwa remaja wanita biasanya cenderung lebih terbuka dan memiliki banyak jejaring di lingkungan sekitarnya. Selain itu, adanya PSS pada wanita yang mengalami kekerasan juga menurunkan resiko individu untuk menjadi korban kekerasan pada hubungan selanjutnya (Johnson, Zlotnick, \& Perez, 2011). Hal ini sejalan dengan hasil penelitian ini yang menunjukkan bahwa sebagian besar partisipan memiliki skor PSS yang tinggi.

Hasil serupa juga ditunjukkan pada kategorisasi skor PTG yang dilaporkan oleh partisipan, yang menunjukkan sebagian besar partisipan memiliki skor PTG pada kategori tinggi. Peneliti mencoba untuk menjelaskan hasil tersebut dengan menggunakan perspektif usia partisipan, di mana sebagian besar partisipan penelitian ini merupakan remaja akhir. Menurut penelitian yang dilakukan oleh Ogińska-Bulik (2013) remaja akhir biasanya lebih mudah mengalami pertumbuhan psikologis pasca trauma karena memiliki skema kognitif yang sudah cukup matang. Penelitian lainnya mengemukakan adanya keberadaan keluarga, teman dekat, ataupun kerabat lainnya memiliki peran pada kemampuan remaja dalam memproses skema baru yang mengarah kepada PTG (Wolchik dkk., 2008). Sehingga dapat disimpulkan bahwa skor PTG yang tinggi pada remaja akhir dapat dipengaruhi oleh perubahan skema kognitif yang dipengaruhi oleh keberadaan pihak-pihak di sekitar individu.

Seperti yang disampaikan pada paragraf sebelumnya, significant others yang suportif dapat menjadi acuan individu dalam mengambil suatu keputusan, menilai keadaan diri dan lingkungan yang dapat memperkuat dalam membentuk skema baru. Swicker dan Hittner (2012) juga mengemukakan berbagai dukungan yang ditawarkan oleh orang terdekat membantu individu dalam menghadapi emosi negatif pasca kejadian traumatis yang berpengaruh terhadap pembentukan skema. Menurut Tedeschi dan Calhoun (2004) pembentukan skema pada individu yang mengalami kejadian traumatis ditandai dengan individu memahami kejadian yang terjadi pada dirinya dan dapat mengevaluasi kejadian tersebut sehingga memiliki tujuan hidup yang baru. Lebih lanjut, cognitive processing atau proses kognitif yang terjadi pada individu yang mengalami kejadian traumatis mempengaruhi individu mengalami PTG (Tedeschi \& Calhoun, 2004).

Peneliti menemukan adanya perbedaan yang signifikan pada skor PTG antara partisipan yang masih bertahan dengan pacarnya yang abusive dengan partisipan yang telah meninggalkan pacarnya yang abusive. Partisipan yang telah meninggalkan pacarnya memiliki skor PTG yang lebih tinggi dibandingkan dengan partisipan yang masih berada pada hubungan yang terdapat kekerasan di dalamnya. Hasil tersebut sesuai dengan penelitian yang dilakukan oleh Cobb, dkk. (2006) yang mengemukakan bahwa wanita yang meninggalkan pasangannya yang abusive memiliki PTG yang lebih tinggi dibandingkan dengan wanita yang bertahan dengan pasangannya yang abusive. Tedeschi dan Calhoun (2007) mengemukakan bahwa wanita yang meninggalkan pasangannya yang abusive cenderung menemukan perubahan yang lebih positif di dalam diri serta 
memiliki hubungan interpersonal yang lebih baik sebagai hasil dari pengalaman traumatis yang mereka alami. Wanita yang meninggalkan pasangannya yang abusive cenderung berupaya ingin memenuhi tujuan hidupnya (Song \& Shih, 2010).

Partisipan yang memiliki durasi hubungan lebih dari 24 bulan bersama pasangan yang abusive melaporkan skor PTG yang paling tinggi. Sejumlah penelitian menunjukkan bahwa individu yang lebih sering terpapar kejadian traumatis menunjukkan tingkat pertumbuhan yang lebih tinggi (Laufer dkk., 2009)). Hal ini dikarenakan individu yang mengalami kejadian traumatis yang cukup intens dapat memotivasi dirinya untuk menciptakan makna yang lebih positif dari kejadian traumatis yang terjadi (Grubaugh \& Caron, 2007). Dalam hal ini, dapat dikatakan bahwa individu dapat menemukan makna dan nilai baik mengenai kejadian traumatis yang mereka alami. Lebih lanjut, (Tedeschi \& Calhoun, 2004)mengemukakan skor PTG pada individu dipengaruhi oleh cara individu memandang kejadian traumatis tersebut sebagai makna dari kehidupan. Hal tersebut dapat terjadi karena adanya pengaruh dari significant others yang membantu individu dalam menemukan makna positif dari kejadian yang dialami (Wolchik dkk., 2008).

Perbedaan budaya dapat mempengaruhi bagaimana individu memberikan respons terhadap trauma (Bernstein \& Pfefferbaum, 2018). Individu dengan kebudayaan Timur cenderung menganut budaya kolektivis, dimana individu tidak dapat dipisahkan dari sosial serta saling membutuhkan satu sama lain. Dengan demikian, individu merasa significant others yang ada akan menyediakan dukungan disaat masa-masa sulit individu (Ammar dkk., 2013). Selain itu, remaja cenderung melakukan suatu tindakan dipengaruhi oleh lingkungan sekitarnya (Larsen \& Luna, 2018). Jika dikaitkan dengan hasil penelitian ini, maka budaya kolektif yang ada di Indonesia dapat menjadi salah satu faktor tingginya skor partisipan pada variabel PTG dan PSS.

Penelitian ini memiliki beberapa kelebihan, antara lain adalah penelitian ini mampu untuk mengungkapkan faktor yang dapat mempengaruhi PTG dengan menggunakan uji statistik pada data demografi partisipan. Faktor yang diuji menggunakan uji statistik dapat memperkaya penelitian pada bagian analisis tambahan. Selain itu, penelitian ini memiliki jumlah sampel yang cukup banyak. Kline (2005) mengemukakan jumlah sampel yang lebih dari 200 partisipan dikatakan sebagai jumlah sampel yang besar. Kelebihan lainnya, penelitian ini spesifik kepada remaja wanita yang mengalami kekerasan dalam pacaran, sedangkan di Indonesia penelitian mengenai remaja wanita yang mengalami kekerasan dalam pacaran belum cukup banyak. Kelebihan lainnya adalah pada penelitian ini juga dilakukan screening menggunakan TALE Checklist, sehingga dapat dipastikan bahwa semua partisipan mengalami kejadian traumatis berupa KDP.

Selain kelebihan, tidak dipungkiri penelitian ini juga memiliki kekurangan. Salah satunya adalah faktor-faktor yang dapat menjelaskan PTG dan PSS pada bagian teoretis tidak semuanya dapat diukur dalam penelitian ini. Salah satu faktor yang dapat menjelaskan PTG dan PSS pada partisipan yang tidak diukur dalam penelitian ini adalah 
religiusitas. Salah satu faktor yang dapat menjelaskan PTG dan PSS pada partisipan yang tidak diukur dalam penelitian ini adalah religiusitas seperti pada penelitian Millam, RittOlson, dkk. (2015). Selain itu, aspek religiusitas itu sendiri memiliki kaitan yang tinggi dengan masyarakat Indonesia (Damarjati, 2020). Dengan demikian, penelitian ini tidak dapat menjelaskan secara rinci mengenai faktor-faktor yang dapat mempengaruhi PTG dan PSS.

\section{SIMPULAN}

Penelitian ini menunjukkan bahwa perceived social support (PSS) berperan signifikan terhadap posttraumatic growth (PTG) pada sampel berupa remaja wanita yang mengalami KDP. Selain itu, penelitian ini juga menemukan bahwa partisipan yang sudah meninggalkan hubungan yang abusive memiliki nilai PTG yang lebih tinggi dibandingkan partisipan yang masih bertahan dalam hubungannya yang terindikasi sebagai KDP. Ditemukan pula partisipan yang memiliki hubungan yang berdurasi lebih dari dua tahun memiliki nilai PTG yang lebih tinggi dibandingkan partisipan dengan durasi hubungan kurang dari dua tahun. Selain itu terdapat beberapa faktor yang dapat menjelaskan PTG namun tidak semuanya dapat diukur dalam penelitian ini. Untuk penelitian selanjutnya, disarankan dapat mengukur faktor-faktor lainnya, seperti sumber dukungan sosial (misalnya orang tua, teman sebaya ataupun kerabat yang pernah mengalami hal yang sama). Selain itu, faktor kepribadian dan religiusitas juga menjadi faktor-faktor yang dapat diukur sehingga dapat memperkaya hasil penelitian. 


\section{DAFTAR PUSTAKA}

Ammar, D., Nauffal, D., \& Sbeity, R. (2013). The role of perceived social support in predicting subjective well-being in Lebanese college students Lübnanlı üniversite öğrencilerinde, algılanan sosyal desteğin öznel iyi oluş üzerindeki yordayıcı rolü. The Journal of Happiness \& Well-Being, 1(2), 121-134.

Anderson, K. M., Renner, L. M., \& Danis, F. S. (2012). Recovery. Violence Against Women, 18(11), 1279-1299. https://doi.org/10.1177/1077801212470543

Bernstein, M., \& Pfefferbaum, B. (2018). Posttraumatic Growth as a Response to Natural Disasters in Children and Adolescents. Current Psychiatry Reports, 20(5). https://doi.org/10.1007/s11920-018-0900-4

Brown, A., Cosgrave, E., Killackey, E., Purcell, R., Buckby, J., \& Yung, A. R. (2009). The longitudinal association of adolescent dating violence with psychiatric disorders and functioning. Journal of Interpersonal Violence, 24(12), 1964-1979. https://doi.org/10.1177/0886260508327700

Cann, A., Calhoun, L. G., Tedeschi, R. G., Taku, K., Vishnevsky, T., Triplett, K. N., \& Danhauer, S. C. (2010). A short form of the posttraumatic growth inventory. Anxiety, Stress and Coping, 23(2), 127-137. https://doi.org/10.1080/10615800903094273

Fydrich, T., Geyer, M., Hessel, A., Sommer, G., \& Brähler, E. (1999). Fragebogen zur Sozialen Unterstützung (F-SozU): Normierung an einer repräsentativen Stichprobe. Diagnostica, 45(4), 212-216. https://doi.org/10.1026//00121924.45.4.212

Jouriles, E. N., McDonald, R., Mueller, V., \& Grych, J. H. (2012). Youth Experiences of Family Violence and Teen Dating Violence Perpetration: Cognitive and Emotional Mediators. Clinical Child and Family Psychology Review, 15(1), 5868. https://doi.org/10.1007/s10567-011-0102-7

Kunst, M. J. J. (2011). Affective personality type, post-traumatic stress disorder symptom severity and post-traumatic growth in victims of violence. Stress and Health, 27(1), 42-51. https://doi.org/10.1002/smi.1318

Larsen, B., \& Luna, B. (2018). Adolescence as a neurobiological critical period for the development of higher-order cognition. Neuroscience and Biobehavioral Reviews, 94(September), 179-195. https://doi.org/10.1016/j.neubiorev.2018.09.005

Laufer, A., Raz-Hamama, Y., Levine, S. Z., \& Solomon, Z. (2009). Posttraumatic growth in adolescence: The role of religiosity, distress, and forgiveness. Journal of Social and Clinical Psychology, 28(7), 862-880. https://doi.org/10.1521/jscp.2009.28.7.862

Linley, P. A., \& Joseph, S. (2004). Positive Change Following Trauma and Adversity: A Review. Journal of Traumatic Stress, 17(1), 11-21. https://doi.org/10.1023/B:JOTS.0000014671.27856.7e 
Mardiah, A., Satriana, D. P., \& Syahriati, E. (2020). Peran dukungan sosial dalam mencegah kekerasan dalam pacaran: Studi korelasi pada remaja di Jakarta. Jurnal Psikologi Ulayat, 4(1), 29-42. https://doi.org/10.24854/jpu57

Ogińska-Bulik, N. (2013). Review article The role of social support in posttraumatic growth in people struggling with cancer. Health Psychology Report, 1, 1-8. https://doi.org/10.5114/hpr.2013.40464

Pico-Alfonso, M. A., Garcia-Linares, M. I., Celda-Navarro, N., Blasco-Ros, C., Echeburúa, E., \& Martinez, M. (2006). The Impact of Physical , Psychological , and Sexual. Journal of Women'S Health, 15(5), 599-611.

Rahmah, S., Magister, P., Psikologi, P., \& Mada, U. G. (2017). Post traumatic growth on aceh adolescent conflict victim. 2(4), 184-198.

Rodriguez, M. A., Heilemann, M. S. V., Fielder, E., Ang, A., Nevarez, F., \& Mangione, C. M. (2008). Intimate partner violence, depression, and PTSD among pregnant latina women. Annals of Family Medicine, 6(1), 44-52. https://doi.org/10.1370/afm.743

Song, L. Y., \& Shih, C. Y. (2010). Recovery from partner abuse: The application of the strengths perspective. International Journal of Social Welfare, 19(1), 23-32. https://doi.org/10.1111/j.1468-2397.2008.00632.x

Swahn, M. H., Alemdar, M., \& Whitaker, D. J. (2010). Nonreciprocal and Reciprocal Dating Violence and Injury Occurrence among Urban Youth. The western journal of emergency medicine, 11(3), 264-268.

Tedeschi, R. G., \& Calhoun, L. (2004). Posttraumatic Growth: A New Perspective on Psychotraumatology. Psychiatric Times, 21(4), 8-14.

Vagi, K. J., Rothman, E. F., Latzman, N. E., Tharp, A. T., Hall, D. M., \& Breiding, M. J. (2013). Beyond Correlates: A Review of Risk and Protective Factors for Adolescent Dating Violence Perpetration. Journal of Youth and Adolescence, 42(4), 633-649. https://doi.org/10.1007/s10964-013-9907-7

Wolchik, S. A., Coxe, S., Tein, J. Y., Sandler, I. N., \& Ayers, T. S. (2008). Six-year longitudinal predictors of posttraumatic growth in parentally bereaved adolescent and young adults. Omega: Journal of Death and Dying, 58(2), 107-128. https://doi.org/10.2190/OM.58.2.b

Xia, L. X., Liu, J., Ding, C., Hollon, S. D., Shao, B. T., \& Zhang, Q. (2012). The relation of self-supporting personality, enacted social support, and perceived social support. Personality and Individual Differences, 52(2), 156-160. https://doi.org/10.1016/j.paid.2011.10.002

Žukauskienè, R., Kaniušonytė, G., Bergman, L. R., Bakaitytė, A., \& TruskauskaitėKunevičienè, I. (2019). The Role of Social Support in Identity Processes and Posttraumatic Growth: A Study of Victims of Intimate Partner Violence. Journal of Interpersonal Violence. https://doi.org/10.1177/0886260519836785 